\title{
Rethinking mission, missions and money: A focus on the Baptist Church in Central Africa
}

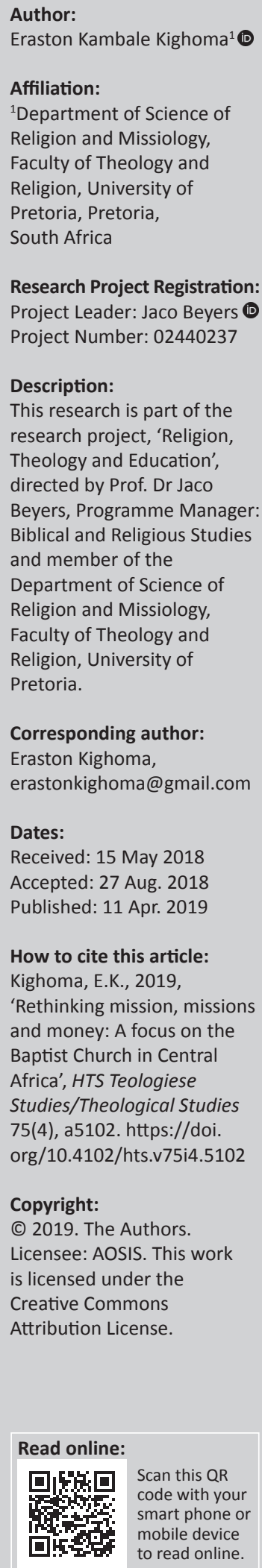

The African church has the most growing figures compared to the west and yet it contributes the least to world missions. This article analyses the issue of disparity in funding mission practices between the African church and its mother church, the Western church. It then explores reasons behind the African church's struggles to support missions and identifies opportunities for world missions to which the eastern Congolese church is exposed. A critical analysis of different arguments and reports from different authors was used to draw the main conclusions and, therefore, identify the central reason of the disparity and provide recommendations for the two churches. The paper suggests how scholars and the church should rethink mission, missions and money in Eastern Congo.

Keywords: Mission; Missions; Money; Baptist Church; Central Africa.

\section{Introduction}

During a tour to visit churches of the Baptist Church in Central Africa with a short-term intern from outside Africa, Nehemiah, the youth leader noticed that children asked for sweets and biscuits from the missionary. John shook his head and told the kids: 'I don't have money'. The children then laughed and told him 'Muzungu masikini' meaning 'poor white man'.

In addition to existing universally accepted principles concerning the distribution of wealth, the fact that the church in the West has to continue supporting the church in Africa seems to be worth considering. Both Westerners and Africans assume that the West is wealthy, and Africa is poor in terms of financial resources. The question of how the so-called 'imbalance in the relative wealth of evangelizer missionaries and those among whom they work distorts the transmission of the gospel' (Bonk 2006:xi) is not so relevant in today's context where each African country experiences particular contexts (Wheeler 1989:1), and especially in Eastern Congo where the local wars affect the church's mission and the evangeliser is not necessarily from the West or wealthier compared to the one being evangelised. But what is relevant in that context, and the issue being addressed in this article, is to question and analyse the disparity in financial mission practices between the African church and the Western church.

In 1989, the Conservative Baptist Foreign Mission Society (CBFMS) had 568 missionaries overseas and declared an income of \$1 420000 to support overseas missions (Roberts \& Siewert 1989:54-56). In 2004 the same missionary society had 558 missionaries overseas and declared an income of $\$ 19155068$ for overseas missions (Bonk 2006:9). The church in Africa, which has the fastest growth rate, has no significant statistics to provide in terms of overseas missionaries, as the Western Church had maintained the practice of funding missions in the global South. But, the DRC, for example, with a Christian population of 73384000 , had an annual growth rate of $2.73 \%$ in 2015 (see Center for the Study of Global Christianity 2015).

The West, however, has become a field for re-evangelisation and Africa is expected ${ }^{1}$ (by the global church) to give back to the West by sending missionaries and supporting them with African money. The need is even acknowledged by Western Christians who 'recognize that they are both the agents and the objects of mission; that those, the evangelizers also need to be evangelized' (Scherer [1999] 2005:15). Unfortunately, the African church is still receiving support from the same West. It should be noted that the same African church has access to resources; in the Baptist Church in Central Africa (CBCA), for example, members hold themselves responsible for funding local church buildings.

It is a contradiction in terms that the church in Africa struggles to support missions while it has riches. Looking at the contrast and what is called imbalance in wealth distribution between the 1.It is said that: 'There are more evangelicals in Africa than in all of North America and Europe combined' (Center for Mission Mobilization 2015:11). 
West and Africa, the issue of disparity of wealth between the West and Africa is said to be the reason why the African church is still depending financially on the West, but this is not convincing. Another reason, more important than the imbalance of wealth distribution needs to be identified, and concrete steps taken to involve the African church in general, and the Baptist Church in Central Africa (CBCA) in particular in an exercise of rethinking mission, missions and money in this particular context. The CBCA is the first to have benefited from the CBFMS support in Congo during the period of the Second World War.

Using the case of the CBCA, this article argues that the church in Africa has sufficient funds to mobilise and support its own mission and contribute toward the funding of World Missions, but, according to the author, it struggles to do so for a variety of reasons: (1) lack of clear understanding of the missional nature of Scripture, having only captured its evangelical dimension; (2) a heritage from the missionaries that did not allow their gospel to adequately address material realities; (3) continued dependence upon the West, predicated upon a false comparison of African poverty and Western opulence; and (4) lack of a mission strategy due to a lack of, or a poor, curriculum of the theological education of church leaders and/or missionaries.

\section{Misunderstanding of mission and missions}

My early childhood was spent in Manguredjipa, situated in the northern part of the North Kivu province in the Democratic Republic of Congo (DRC). My father was very committed to the life of the Baptist church, especially in evangelism and the music team. He had migrated from his native area to that part of Eastern Congo and had been involved in the establishment of the church at Mataba. I grew up with indigenous children who were from the 'Piri' and the 'Wapakombe' ethnic groups. One of the challenges of evangelism that our parents faced was that the Wapiri were not identifying with Christianity. They would tell evangelists their common slogan saying: 'After you killed your Jesus in Butembo $^{2}$ then you come here to tell us that he died for us'. This is a misunderstanding of mission and missions.

The New Testament owes its existence to 'God's heart for the world and the efforts of God's people to spread the message of God's love' (Williams 2012:49). Joel F. Williams (2012) argues that:

The Gospels present the mission of Jesus, God's Son, who came to provide salvation through his death and resurrection. He has sent his followers out on a mission to make disciples of all nations. (p. 66)

It is clear that Jesus is presented not only as a sent missionary but also as the one sending missionaries who could hand down the message to his followers so that they would go out and make disciples. When the gospel was first presented in

2.Butembo is located $98 \mathrm{~km}$ east of Manguredjipa and was considered to be a civilised city with which our parents were being identified.
Eastern Congo, it was presented as the 'Good news of the Lord Jesus', a Jesus who was killed for us by his people. And it might have been hard for the receivers of the message to accept that they were to be concerned with the death and resurrection of a foreigner presented by foreigners from either the West or the regions that were first 'conquered' by the missionaries. Furthermore, missionaries presented the gospel as a shift from the Old Testament to the New Testament while God's message for the world does not start with the New Testament.

David Bosch (1991:11-55), in his book, favours Joel F. Williams' view. Bosch argues that there is a fundamental shift regarding the interpretation of 'mission' noticeable in the New Testament when compared to the Old Testament. The missionary character of Jesus' ministry compared to that of the early church, and the way three New Testament authors interpret mission are proof of the shift. If 'mission' is sending preachers to distant places, then I agree with Bosch (1991:17) that the Old Testament does not show that Israel reached out to nations outside its geographical and cultural boundaries with its faith. However, the story of Jonah appears to contradict Bosch's idea. Jonah's mission was to bring a message of redemption to Nineveh, which is the present-day Iraq and which was outside Israel's geographical boundaries and culture. God sent this Jewish messenger, who had a negative attitude and understanding of God's will, to the Gentiles. It is true that the Jews never converted the Gentiles, though called to bear witness to the nations as Genesis 12:1-3 gives the mandate, 'foreigners (Gentiles) adopted the group obligations and became [a] full-fledged part of Israel' (Goheen 2011:24). The Gentiles' initiative to be followers of Judaism, which bore their attraction and was accredited by the requirement to obey the Torah, could likely be identified with today's missional practices. Today's church members do not live apostolically, they do not consider themselves as missionaries, they do not routinely introduce new believers to the faith in Christ, et cetera (cf. Minatrea 2004:184-195). During his ministry: 'Jesus selected twelve disciples to be with him and he sent them to twelve tribes of Israel' (Bosch 1991:26) that were to receive the gospel and mission and, therefore, this became the proclamation of victory for all nations on earth. Although it took time to acknowledge the Gentiles' participation, the exiled Hellenistic Christian church of Antioch inaugurated a harmonised church for both Jews and Gentiles and the beginning of the worldwide mission in sending Paul and Barnabas to the nations.

The shift in the understanding of mission is not very helpful in such contexts as that of Manguredjipa in Eastern Congo. Christopher J. Wright counters the views of Bosch and Joel F. Williams and argues that: 'Mission is what the Bible is all about' (Wright 2006:29). He defends his idea by saying that ' $i$ i]n a missiological approach to the Bible' it is not to say that:

[E] every sentence of the Bible talks about evangelism but with the term 'Mission', we are thinking of the purpose for which the Bible exists, the God the Bible renders to us, the people whose identity and mission the Bible invites to share, the story the Bible tells about the whole world and its future. (p. 31) 
The love of God has a story that needs to be told in its entirety to people who are being reached for in Christ. In the case of Eastern Congo, people were told to repent of the past as well as for some of their cultural and behavioural practices that were helpful for life as an individual and as a community. If the pastor saw you preparing medicine from wild leaves, you were to be excommunicated from the assemblies of believers because the gospel message was about forgetting the past and starting an alliance with the God of the New Testament. It is here where this church in its early times missed the point. Everything you possessed was not to be considered as an input to help spread the gospel. The West had the best things to offer, starting with the gospel, and individual believers as well as communities of faith therefore lost confidence in what they possessed; they turned their confidence to the power of money, which was being brought by missionaries, who were, in the case of Eastern Congo, government officials. Therefore, their possessions, that is, their values, solidarity, and material belongings which could have been developed toward capitalised wealth and investment to create not only unity, but the African church's contribution toward the funding of the World Missions - did not materialise.

Today the church's mission is being understood to have two interests, that is, a cultural mandate and an evangelical vocation (cf. Beals 1988:3). Therefore: '[E]verything the church is sent in the world to do is mission' (Beals 1988:3). The CBCA, however, is still holding the view of mission as its evangelical aspect only. It has a Department of Mission and Evangelism and Life of the Church responsible for reaching out to people for Christ, at every local level of the church, through the evangelistic team called 'the evangelism commission'. A missionary is, therefore, not understood to be, as every Christian, 'learning and adapting to the culture around while remaining biblically sound' (Stetzer 2006:19) but as either a white person from the West or a church member commissioned by the church to go and serve a certain purpose outside the church denomination. The understanding of who a missionary is, is thus limited to the restricted view of evangelism. Operating under such conditions as in Goma, where migrations due to wars in the region took place and a cross-cultural community came into existence, the church has not been able to develop mission-minded and missional local churches, which can be on-mission by being intentional and deliberate about reaching out to other people, and adopting the attitude of a missionary church (Stetzer 2006:19). This situation, therefore, confirms that the church in Eastern Congo misunderstood the concept of mission, missions and a missionary.

\section{Disparities (differences) in fundraising approaches}

There has been a disparity in the fundraising approaches between the Western church and the African church, trying to address the issue of whether the flow of a large amount of money from North to South is still needed. Walbert Bühlmann (2006:xi-xiii) is positive about the flow of money due to the fact that the life of the church will always need money. However, his 'yes' is conditioned by 'the allocation of the fund to be done in the right proportions and with full knowledge that [it] will not corrupt the evangelization process' (Bühlmann 2006:xi). He argues that: '[The] transmission and enculturation of the gospel is affected by the imbalance in the relative missionaries and those among whom they work' (p. xi). Through the fact that such support is a one-way donation, the mission establishes a church that will never follow the church planting movement approach and, therefore, will remain dependent on the sending church. What will happen if the North continues to support the South? We cannot discourage the North to continue supporting the South - there is an urgent need for the southern church to be prepared to support its missions and become prepared to be part of supporting global missions. Some African churches are well equipped and can support missions, while some might need continued assistance. But both need directives on the sound use of money, a gift from God, and how to guard against dependency scenarios that perpetuate the myth of Africa as being poor. On the other hand, the North, during the colonial era, was supporting missions in the South because of the availability of funds but due to a vibrant fundraising system, which still needs to be understood and learned from by the African church.

\section{Fundraising for the missionary work in Africa}

In many cases, missionaries were sent by mission societies from the West. There were both denominational mission societies, such as the Church Missionary Society (Robert 1994:258), and interdenominational societies. The interdenominational mission societies consisted of two categories: those founded by the councils of denominational churches such as the CBFMS (cf. Shelley 1981:37-47) and those founded by private and non-denominational missionaries such as the 'faith mission' called China Inland Mission founded by Hudson Taylor (Tuttle 2006:318). Each society was overseen by a mission board that was recruiting missionaries and mobilising funding to support the mission work. The Home Mission Board of the Southern Baptist Convention received \$19 000 annually to support over 100 missionaries serving almost 400 churches in 1860 and the Women's Missionary Union of the same Convention raised $\$ 10000$ from 57 young women to build the school for women in 1917. From this example, it is clear that both churches and individuals were donors to support missionaries and that mission boards were acting as channels to reach missionaries in the field with support. However, we have to note that Western missions varied greatly with great disparity, even in the support that Western missionaries received.

Regular mission reports were motivators for new fundraising actions. Upon hearing from Adoniram J. Gordon's report of Congo that the new Baptists needed a chapel, the Claredon Street Church raised $\$ 2500$ and sent a complete prefabricated chapel by steamship (Robert 1994:20). With such cases, one is likely to think that missionary support was results-oriented and that missionaries who were not writing home for any 
reason might have been obliged to quit the mission field or be forgotten by their home churches and sending mission organisations.

The second category of funding missionaries was the support from missionary families and friends. Missionaries would ask their families to either support their mission work fully or contribute a part of their upkeep to the field. Dae Young Ryu says that: 'Some of these educated young men and women who went as missionaries were from [the] comfortable middle-class' (Ryu 2001:93). It is reported that, during the period of 1905-1909, 81 out of 135 new American missionaries who sailed for Korea were, Student Volunteer Movement (SVM) volunteer families that became American missionaries in Korea (Ryu 2001:97). But among the faith-based missions, such as the Africa Inland Mission (AIM), the missionaries tended to come from rural regions, were poorer, and less educated. Dick Anderson (1994:17-18) reveals, for example, that even the founder of AIM, Peter Cameron Scott, was from a poor family, which 'owned little of this world's goods' but joined the mission work together with his brother for the Congo mission in 1889. Furthermore, of great impact were the contributions of spouse and parents of certain Western missionaries. The parents of some missionaries were contributing by taking care of the pre-school grandchildren in their homes and this allowed missionaries to be more effective in most dangerous mission fields (Steffem \& Douglas 2008: 276). It is, therefore, assumed that parents were responsible for funding the needs of missionary kids whose parents had no support from a well settled organisation.

The last category of missionaries to the South was that of tent makers. Motivated by their missionary call, many Christians were using their career to fulfil their missionary duties. Tony Wilmot, for example, a British businessman, initiated the student movement, called the Pan-African Fellowship of Evangelical Students (PAFES), in African English-speaking countries during his business tour to Africa in 1958 (cf. Groupes Bibliques Universitaires d'Afrique francophone n.d.).

The case of Jacques André Vernaud, a Swiss citizen, who established the Assemblies of God in Congo, reveals the role of women in missions in the Congo. Jacques and Johanna Vernaud settled in Kinshasa, then Leopoldville, in 1965. The first years of Vernaud in Leopoldville were full of hardships. Cut off from the support of the Assemblies of God and France, the family had to rely on only one income, that from Mrs. Vernaud who had to take a small job and worked as a midwife at the General Hospital (Eglise La Borne n.d). This allowed Jacques Vernaud as head of the church to establish many churches, including the prestigious CEF-La Borne (Centre Evangelique Francophone- Francophone Evangelical Centre) in Kinshasa.

The Baptist Church in Central Africa has had missionaries from the first and the second category. Charles Erwin Hurlburt was a founder and general director of the AIM (cf. Gerhman 2004:125). The CBCA (2013:44) stated, that after he had had an experience as AIM director following the death of Peter Cameron Scott in the 1890s, 'he decided to evangelize the unreached Africa' and, therefore, founded the Unevangelized Africa Mission (UAM), a family and private missionary organisation. He put the Mission under the leadership of his son, Paul Hurlbert. Little is written about the UAM. The Baptist Church, by then the UAM, was registered as a domestic non-profit business incorporated in California, United States of America (USA) on March 10, 1928 with the registration number C0127979 (cf. Unevangelized Africa Mission n.d.). The Baptist Church in Central Africa (CBCA in short) is a Church born from the work of the UAM, a mission institution founded in America in 1927. History tells that: 'Later on, in 1946, the UAM handed over its mission field to the CBFMS (CBCA 2013:44). In 1957, CBFMS became "Mission Baptiste au Kivu" (MBK)' (CBCA 2011a:44). Little is also known about 'the agreement with the UAM which made possible the entrance CBFMS in the Congo' (CBCA 2011a:49). It is this particular agreement that determined the shift of the Baptist Church from being funded by the Hurlburt family to being fully supported by Baptist churches from the US. During its first four months, CBFMS received $\$ 42000$ from over 200 churches (CBCA 2011a:45), which may have been allocated to the only mission work located in Eastern Congo.

\section{African fundraising for sending African missionaries}

The African believers were "called "native" and considered as immature and therefore were voiceless in the church councils' (Baker 1926:402) during the Westerners' church leadership in Africa. And so, they had to rely on their mother churches for funding even after the missionaries withdrew and, therefore, the idea of poverty of the global South took roots. It becomes a bit of a deep narrative believed by both sides of the Atlantic and perpetuated by Africans and Westerners alike. This has always made both sides unable to recognise, like Moffatt did, that Africans:

$[H]$ ave become rich in a variety of acquirements, favoured above measure in the gifts of providence, unrivalled in commerce, preeminent in arts, foremost in the pursuits of philosophy and science, and in all blessings of civil society. (Bonk 2006:3)

Rather than using these riches as opportunities to send missionaries outside their denominational boundaries, many African churches have continued to believe in the power of the disparity of the availability of resources between the West and Africa. Consequently, these churches were not sending missionaries outside their settings. The few poorer missionaries in the West were seldom acknowledged as missionaries, their status of being African missionaries hindered them from gaining trust from both their own churches and the Western churches. In most cases, they are perceived as less than pastors, as poor, as uneducated, as adventurer migrants, et cetera. Since they are not associated with any agency other than their sending churches and since their cross-cultural missionary endeavours are restricted by the bounds of their own countries (Bonk 2006:15), rather than calling them national evangelists as Jonathan J. Bonk does, I will say they are transplanted evangelists. They are limited to 
reaching out to their fellow poor citizens in the Western countries. This is a big mistake that the church has made to look down on itself regarding its capacity to fully fund its missions. It is clear that before we can reshape the missional nature of the churches, we have to wrestle with the status of missionaries on the continent.

The case of the CBCA fits the context here, described above. From its statistics provided below, this church appears to be doing well as it is reported that:

The CBCA has more than 450000 members (children included) in 404 parishes lead by 704 ordained pastors, 180 retired pastors and it cares for 130 widows of pastors. It runs 506 schools among which 18 nursery schools, 342 primary schools and 145 secondary schools in different domains. In the health sector, the CBCA runs 3 hospitals, 17 surgical medical centres, 41 health centres, 80 health stations, and 4 medical schools. To fight illiteracy, CBCA organizes 135 training centres for the youth and adult people. Most of CBCA pastors are trained in 2 Bible schools and at ULPGL. CBCA has many socioeconomic development projects, 3 big HIV/AIDS centres with a coordinating office in Goma supported by our partners, and 1 demobilization centre for child soldiers. (Baptist Church in Central Africa n.d.)

It is, however, interesting to discover that with these statistics, the CBCA is still using foreign money, both for its projects and supporting its few missionaries outside. Through its partnership with the United Evangelical Mission (VEM), the church has sent missionary doctors into Tanzania and has currently a theologian pastoring a German church with a missionary status (cf. Bulletin Bimensuel d'information de la Communauté Baptiste au Centre de l'Afrique 2013:3). I attended a farewell for an expert and his family who were being commissioned by the church in Goma to a church in the Equatorial Province in Congo as 'Missionary of the United Evangelical Mission'. The family will be paid by VEM and not by the mission department of the CBCA. Rather than calling it a missionary sending, it is clear that it is likely to be a job recruitment by VEM from the CBCA. Thus, no church member knows how the money to support missionaries from the church should be raised and may therefore still believe that a missionary is paid from abroad when he or she could be able to contribute to the mission.

Surprisingly, the war and poverty in Eastern Congo is not a hindrance for church members to support the church mission. During the farewell and commissioning of missionaries, I witnessed that another missionary was being sent as a church planter to Maniema; he was not to be supported by a foreign fund. No plan and/or philosophy of support were given to participants for his survival in Maniema. The Bulletin Bimensuel d'information de la Communauté Baptiste au Centre de l'Afrique (2013:3) states that during the service, members incidentally made 'a quick resource mobilization and gathered a hundred sheets, bags of cement as well as several other contributions that will allow the construction of the Temple of Kindu'. This therefore supports our argument that poverty in the South is not a reason that hinders the African church from supporting its missions.

\section{Indigenous contributions towards mission work}

It is true that: "[T]he so-called "natives" were still immature in running church businesses' (Baker 1926:402). However, this is not a reason to exclude their voice on church councils. For example, while history tells that Paul Hurlbert led the team of delegates from Eastern Congo to the first missionary conference held in Stanley-Poll (Kinshasa), no native is said to have been part of such a strategic gathering. History seems to ignore a series of annual gatherings entitled 'the General Conference of Protestant Missions' from 1902 to 1911; this is due to the fact that natives were not part of such leadership gatherings. Since they were responsible for the establishment of new churches, they had to run these churches with no experience in leadership. The fact that they were unable to attended the mission leaders' consultation gatherings - which not only provided vision but also shaped it for the new communities of faith - the 'native' had no clue on how to ensure a continuity of possession. The succession model used by missionaries was not in line with the biblical models of succession as far as church planting was concerned because the 'ownership is maintained through succession [...] and the object of succession is an institution' (Stepp 2005:193). Using the experience of Uganda, Louise Pirouet (1978:2) attributes the rapid expansion of the church to the 'catechists' who courageously took the gospel to other citizens from the city to the rural areas, while most of them survived in the field without any support. The missionaries' contribution toward indigenous preachers' work was more technical and social. Western missionaries gave them plans to reach the unreached and had to train them on a crash course basis to enable them to communicate the biblical message. Then they provided clothes to wear, food to eat, and a house to live in for the preachers and communities (cf. Pirouet 1978:12). This led to a disconnection between the gospel and the material needs of the people. What was missing in the process was to communicate the character of the ownership of the missions, which consisted in teaching them how to fund and fundraise for missions locally and how to keep the funding system sustainable.

\section{The colonial legacy and the view of the church about money}

African Christians were not taught how to support the missionary efforts. Archibald G. Baker (1926) said that:

During the nineteenth century mission theories were dominated by the conception of divine authority, revelation, and power. Therefore, the missionary spoke with the authority of the prophet and administered in the name of God. (p. 402)

They taught their followers that ministry is about suffering in obedience to God. This explains the Anglican song entitled 'Go to the World! Go Struggle, Bless, and Pray' (Hiltz 2008:307). One of the pioneers of church planting who served with the first missionary of UAM, related through oral 
history that the missionary would send one of them to take a parcel from Kitsombiro to Katwa on foot while he would drive to the same destination believing that suffering was part of the training he gave the locals.

The missionaries concentrated their efforts on spiritual aspects of Christianity. There was no room for holistic mission. Missions contributed much to sustain poverty in Congo. From the speech of King Leopold II of Belgium to Missionaries, Leopoldville, of 12 January 1883, it is drawn that the missionary mandate from the coloniser country was: to make every effort so that the black people never become rich. To make them sing every day that it is impossible for a rich man to enter the kingdom of God.

They taught the Congolese that 'reward' for church services would be received in heaven predicated on a special kind of eschatology. This explains why churches became unable to take care of their personnel even while experiencing growth in attendance as a result of the efforts to establish churches that followed the withdrawal of Westerners. The Congolese Kiswahili use the word Mutume [apostle] for the worker and Kitume [apostolate] for the work that does not need payment. Another word used by CBCA is the phrase Kazi ya kanisa [work of the Church] or Kazi ya Mungu [work of God] and when it is used, every believer is aware that it is voluntary service.

The culture of volunteer ministry is one of the very negative legacies from the missionaries who gave catechists food, clothes and housings for their work. The CBCA took it to be a worthy legacy and as the only payment or support a missionary deserved from the church denomination. In a discussion I had with one of the pastors of this church in Goma a few years ago, he revealed that the reason he resigned from pastoring a specific church in 2006 was that he was undermined by the church council, which considered him as not being spiritual as he tried to challenge the council to increase his salary - it was fifty dollars, which could not take care of his family in the city. To a certain extent, this attitude came from the faith-based missions. Paul Hurlbert, being a direct descendant of Charles Erwin Hurlbert, a co-founder of a faith-based mission, could not have run this Church established by him and could not promote among evangelists the dependence on God for their well-being.

\section{Theological education and the challenge to fully fund missions}

According to Manfred Waldemar Kohl (2005:10): 'Pastors, missionaries, and evangelists put into practice what they learn, and pass on their experience to people in their churches, mission work, or outreach ministries'. Education provides intellectual preparedness and sharpens the mind of anyone for any specific task to which he or she is assigned in his or her specific culture and context in a dynamic way. Kohl opposes the slogan recalled by Fred Hiltz: 'Go to the World! Go Struggle, Bless, and Pray' (Hiltz 2008:307). This was written by Sylvia G. Dunstan and 'appears in the mission section of Common Praise, a 1998 hymnal of the Anglican Church of Canada' (Dunstan in Hiltz 2008:10), to capture 'the very essence of theological education for the future church, a future into which we are being drawn even now' (Hiltz 2008:10). It is wrong to confuse missionary work with a ministry service filled with struggles and challenges due to a lack of education of the missionary; however, it is also wrong to say that to be spiritual brings financial prosperity.

What is worse is that many churches and/or organisations sending missionaries into the field, believe missionaries on the ground should, as part of the training of the team, struggle. One of the weaknesses of Paul Hulbert who established the CBCA, was that, though he was very aggressive in sending indigenous believers to establish churches, he did not consider educating them before they were sent. Oral history transmitted for generations reports that he was convinced that a baptism class was enough to equip them for the ministry. A day after his baptism, my late grandfather was sent to start a church, which he never succeeded to establish due to a lack of not only theological education but also the fact that he had no education at all.

From the research data I conducted in Goma concerning missiological education in Eastern Congo, the CBCA is still not able to send its missionaries and support their well-being. This is because of a poor educational background of its mission field pastors, a geographical disparity of theologians within the denomination; the theological curriculum used by the theological institution that trained most theologians is not fit to prepare theologians who will face the challenges of church planting in the region. The fourth reason and main cause of the first three is the lack of a mission strategy, even though the church has a structured department of Mission and Evangelism and Life of the Church.

\section{The educational background of pastors in the mission fields}

The CBCA has the so-called 'Shamba Mpya', areas targeted for the establishment of new churches. In the process of church expansion inside the country and abroad, Rwanda was the first foreign country to be reached where four missionary stations are being established. Our interview with the secretary of the Department of Evangelism and Mission and Life of the Church and documentary analysis revealed that the Church has a total of 25 church planters in six different areas. According to the interviewee, none of the 25 church planters was sent by the church but most of them, in search of survival and daily bread, found themselves in areas where there was no church and decided to gather people under the banner of their mother church. In the case of Rwanda, Kamuha Musolo W'Ivuka quotes Muhindo Kasekwa (2008), who reveals in his survey of records of the CBCA that:

[T] he local church that is being established in Rwanda consists of a group of Rwandan refugees returned home to Rwanda, where even their former churches were destroyed by the war, they were 
compelled to start a new church there as a sign of gratitude to the CBCA. (W'Isuka 2009:65)

Fourteen of the 25 church planters (56\%) went to look for fertile farming land and opportunities, three (12\%) have a background in business, two others (8\%) are carpenters, one person is a mason constructor (4\%), and the others' background is unknown (20\%). This suggests that church planters survived without church support because they were able to support their livelihoods using farming products, or cash-for-work jobs, or income generated by their businesses.

When it comes to their educational background, the most learned church planters are those 15 (60\%) with either two or four years of Bible school education. It is interesting to notice that $60 \%$ of the church planters are ordained ministers and $40 \%$ are evangelists. A missionary and/or church planter is a low-status position, perhaps equivalent to being an evangelist under a pastor, but more than a lay person. It seems that in the culture of the CBCA, once a church lay person obtains Bible education, he or she is first called an evangelist who is to be mentored and then ordained as a full-time pastor. So, church planters are called evangelists due to an error.

The fact that church planters took isolated initiatives to plant churches that they run demonstrates that no strategy of church planting exists, which explains why the department of Evangelism and Mission organised in 2010 'a one-month seminar to train the church planters on church planting and self-supporting' (cf. Kighoma 2012). The report of the 33rd General Assembly of the CBCA held on the Kikyo site in Butembo supports our view that after 85 years of existence the CBCA has no mission strategy. The report says that:

Having realized that there are Christians who are planting churches in new mission fields without following any norm and even in neighboring countries without any financial ability, seeing that there are also chapels being planted without authorization from the church district or mother church, the General Assembly realizes that there should be Mission strategies within CBCA. (Mutahinga \& Midiburo 2011:10)

When there are no mission strategies, the church will be unable to control the volunteers who have the burden to serve God wherever they go. It is the strategy of the mission to include the fundraising and funding functions for missions. The CBCA neither has strategies to raise funds for missions within the church nor does it have a clear plan to support missions on a strategic and well-designed scale. Consequently, the church leaders complained of being overwhelmed by uncontrollable volunteer church planters.

\section{Geographical disparity of theologians in the Baptist Church in Central Africa}

A recent evaluation (see Figure 1) revealed that 92 out of 506 (18.2\%) pastors running stable churches within the CBCA have gone to theological school and the rest have gone to Bible school for either two or four years. It is good to note that this Bible school is the equivalent to secondary school with concentration on biblical studies. While the rural areas

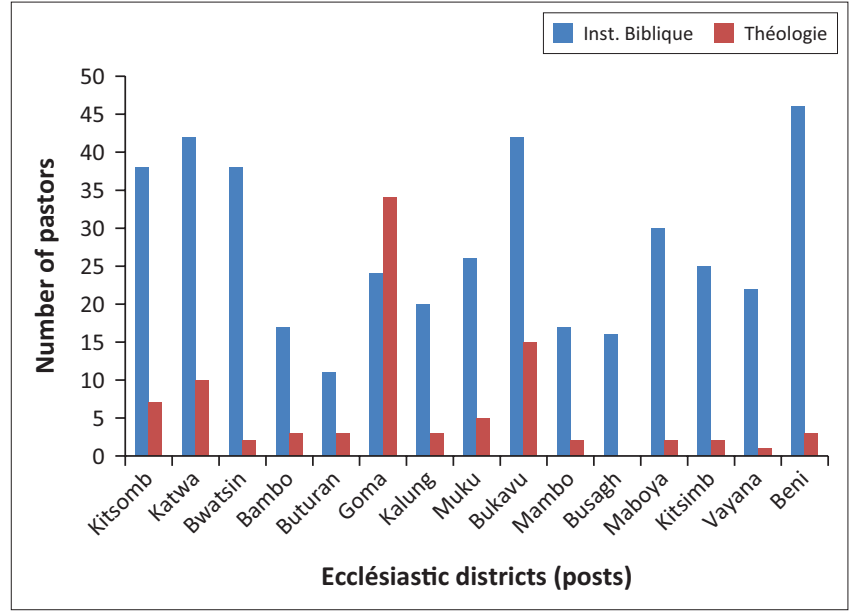

Source: CBCA, Department of Evangelism, Mission and Life of the Church of CBCA, 2011b, 'Effectifs des Pasteurs de la CBCA', unpublished document

FIGURE 1: Pastor's levels of education by district ('Poste').

lack theologians, $67.3 \%$ of theologians are in the cities. For example, the ecclesiastic district of Busaghala has no theologian at all and the district of Beni has the highest number of pastors from Bible schools.

During the Bible study session at the Goma-Ville parish on the 20th of July 2012, the talk with the former President and Legal representative of the CBCA revealed that: '[T] heologians are very selective in terms of the geographic areas of service and always decline the appointments of the church when it comes to the rural areas' (Kighoma 2012). This situation is very risky for the future of the church in the rural areas. It is true that the availability of those called 'Biblistes' in the rural areas in today's context is a proof of their commitment. However, these pastors still are limited in numbers and to leave them at the frontline where a sound doctrine is needed to be taught is a dangerous decision for the church. In addition, to have $67.3 \%$ of all theologians in the cities is a waste of resources. The idea of continuing theological education or refresher courses for pastors is part of the solution.

The report of the President and Legal Representative of the Baptist Church in Central Africa (CBCA) to the 33rd General Assembly reveals that: ' $[I] \mathrm{n}$ the next ten years $40 \%$ of CBCA pastors are going to retire' (CBCA 2011a:10) while the number of students in theological school and Bible schools has decreased. This situation is a catastrophic one and the church is likely to lack ministers and therefore leadership from the younger generation, which is not interested in theological education. It is true that the General Assembly recommended that:

[T] he vocational groups be initiated [...] and the local church initiates the 'Local scholarship' to support theological students', and that 'the Church districts create income generating activities for Pastors' families [...] to attract young people to pastoral service. (CBCA 2011a:10)

From this decision it appears that the issue of money is affecting all the recruited servants of the church to the extent 
that the family members of the pastor of the local church are frustrated by the financial motivation of their spouse or father (pastors are men). When the senior pastor is not being treated well by the church it is hard, if not impossible, for him to plan and mobilise the church he is leading to give funds for missions.

\section{Theological curriculum of ULPGL (Free University of the Great Lakes Countries) compared to the Great Lakes' context and needs}

The fact that: 'Church workers who hold a university level education have been educated within the theological faculties of the four main universities', among which 'ULPGL in Goma, which belong mainly to CBCA' (W'Isuka 2009:114) made us analyse the curriculum of ULPGL where most of the CBCA theologians have been trained.

The Prospectus 2006-2007 (Mutahinga \& W'Isuka 2006:10-13) shows that at the Free University of the Great Lakes Countries (ULPGL) the Faculty of Theology has a five-year BTh programme with a course called 'Practical Theology' in addition to Philosophy, Systematic Theology and Biblical Languages. The course in Anthropology and Sociology appears among the appendix disciplines. It is clear that this curriculum is likely to prepare local church administrators and philosophers, but not church planters or any other missionaries that may be sent to the frontline for strategic missions.

During an interview conducted with Kamuha Musolo in Goma in July, Paul Kamuha Musolo W'Isuka, who is the Mission course lecturer, revealed that: "The five years [sic] BTh program offers only a single two-credit/hours course of Missiology which cannot prepare students for missions'. Furthermore, he revealed in his thesis that: '[T]he entire university library has only five missiology books out of the 8000 volumes, including reviews and journals' (W'Isuka 2009:114).

It is clear that alumni from this theological faculty will not be ready to be sent far from the city for missionary service because they are neither ready for missions nor prepared for it. And when they are pastoring churches that have already been established, they are likely not to make missions part of the church budget plan. Missionary work is seen as a lower status profession, with limited legitimacy and less (or no) funds. Therefore, only amateurs and the alumni from Bible schools are ready to take the risk and plant churches without the support of the department in charge, which is led by theologians supposed to plan and implement the nonexisting mission strategy. During a church seminar I ran on 'missions' in Goma in September 2013, I asked what percentage of the church budget would be assigned to missions and evangelism. The pastor responded that there is no budget planned for that because even the evangelism commission does not submit a budget for their department. Whenever the church talks about missions, the issue of money is not being addressed as how to make missions successful and also the Church budget plan seems to ignore mobilising funds for missions. Money and missions are not going together in churches within the Baptist Church in Central Africa.

\section{Conclusion}

The imbalance in wealth distribution between the West and Africa is not the reason why the African Church and particularly that in Eastern Congo, is still a minor contributor to the universal church and struggles to fund missions, even though it is the fastest growing church in the world.

Instead of the mission being known for its holistic character, the CBCA has a serious misunderstanding and only views mission in its evangelical dimension. The misunderstanding started way back in the beginning of the Church by missionaries who presented the gospel as good news of Jesus brought to the Congolese by foreigners. A shift from the past is required - the church is to shift from its historical understanding of mission.

Since the arrival of Western missionaries to date, mission is not understood as 'everything the church is sent in the world to do' (Wright 2006:29), but rather it is believed to be evangelism carried out by a very particular team within a local church overseen by the department called 'Mission and Evangelism and Life of the Church'. Furthermore, the missionary was first understood to come from the West, then as a church planter sent to distant places to spread the gospel and as someone that had an inferior status to that of a pastor, rather than being understood as being every Christian 'learning and adapting to the culture around while remaining biblically sound' (Wright 2006:31). For that reason, the church has not been on mission, neither has it been able to establish mission-minded churches in the challenging context of war and ethnicity. Therefore, as this article is calling for a holistic approach to mission, it advocates that 'mission' should be contextualised in Eastern Congo.

Accepting that the church in the West continues to support the African church based on the principle of the imbalance of wealth distribution between Africa and the West is 'distorting the transmission and enculturation of the Gospel' (Bonk 2006:xi) - it does not encourage a church planting movement to be a reality by planting self-supportive, self-governing, self-propagating and self-theologising churches. Therefore, the allocation of funds to the African church 'is to be done with full knowledge that avoids corrupting the cross-cultural dimension of mission work' (Bonk 2006:xi). This is only possible when the mother church transfers its missional nature, character and identity to the daughter church rather than creating dependencies. It is important that dependency should be avoided in mission work. Is the continuation of funds from the West related only to the perceived wealth disparity or is it more a matter of controlling the theology and ideology of mission by the West? Mission boards in the West and/or North also need to rethink their theologies, cultural perceptions and strategies concerning mission, in 
dialogue with churches from the South. Furthermore, the daughter church needs to learn from the mother church and be able to evaluate possibilities for it to give back as it continues the process of church planting.

The CBCA, in Eastern Congo, has not yet been able to fund missions because it has no experience and has not been initiated into fundraising and funding processes for the missions. The Western missionaries had various approaches of mobilising support from individuals and families, and churches and boards of missionary societies, or self-support through tent-making. They neither transferred the skills necessary for fundraising and funding of missions to African believers who they considered immature nor did they involve them in the running of missions' leadership business.

The Western missionaries only taught suffering and evangelism to the church and created, therefore, a new culture of free work for the ministry of the church. This mindset has affected the view that family members of ministers hold concerning church ministry to the extent that the Baptist Church is going to suffer a shortage of 40 per cent of its pastoral staff workers over the next ten years if the youth continue to refuse joining theological education.

Our research conducted in Goma identified that the CBCA has not had any mission strategy for the last 85 years. Its Department of Mission and Evangelism and Life of the Church trains its pastoral force at a selected university founded by the Church. The theological curriculum that is followed is not suited to prepare theologians who will face the missionary and financial challenges of church planting in the region and beyond. Consequently, there are serious disparities as far as skills of workers within the church go; theologians take leadership of churches already planted, and the strategic mission field is left to church planters with a poor educational background and volunteer lay Christians. Therefore, the fact that the Church lacks a mission strategy is the reason why it is still unable to send missionaries and fund them after 85 years of fruitful ministry, the few sent missionaries still being funded from the West. The local believers have not yet owned the church fully.

It has been argued throughout this article that poverty in the South is not the reason hindering African churches from supporting missions and thus depending forever on support from the, assumed, wealthy West. The true reason is that the CBCA in Eastern Congo has not been taught how to raise funds and support missions. Pastors wait for their eternal rewards as they struggle to serve while, when the church leadership cannot locally fund a project it relies on the West rather than exploiting available potential sources hidden by the lack of local fundraising. The problem is the poverty of mind of the church in viewing mission, missions, and money; this hinders the church from contributing to the universal church in a way proportionate to its size and recent growth, and also how mission is perceived as a vocation in the ministry of the church.

It is, therefore, imperative to rethink fundraising for the mission and funding for mission strategies. A new direction towards missions is highly recommended with the emphasis on every local church to develop a mission strategy aimed at planting missional churches based on its holistic mandate.

\section{Acknowledgements}

My gratitude to the ASET platform, which created an avenue for me to capture the interest of writing on 'money and mission' in preparation for the 2014 ASET consultation, and to Prof. David K. Ngaruiya for encouragements.

\section{Competing interests}

The author declares that he or she has no financial or personal relationships which may have inappropriately influenced him or her in writing this article.

\section{References}

Anderson, D., 1994, We felt like grasshoppers: The story of Africa Inland Mission, Crossway Books, Nottinhham

Baker, A G., 1926, 'Twenty-five years of thought concerning Protestant Foreign Missions', The Journal of Religion 26(4), 384-402, viewed 03 Nov 2013, from http://www.jstor.org/stable/1195702.

Baptist Church in Central Africa (CBCA), 'United Evangelical Mission in Africa', viewed 06 November 2013, from http://www.vemission.org/en/countries/africa.html.

Beals, P.A., 1983, A people for his name: A church based-missions strategy, Bake Book House, Grand Rapid, MI.

Bonk, J.J., 2006, Missions and money: Affluence as a missionary problem - Revisited, Orbis Books, Maryknoll, New York.

Bosch, D.J., 1991, Transforming mission: Paradigm shift in theology of mission, Orbis Books, Maryknoll, NY.

Bulletin Bimensuel d'information de la Communauté Baptiste au Centre de l'Afrique, 2013, La Trompette, media release $N$ * 70, Nov 2012-Fevrier 2013, Goma, viewed 06 November 2014, from http://www.cbca-kanisa.org/images/no70.pdf.

Bühlmann, W., 2006, 'Missions and foreign money', in J. J. Bonk (ed.), Missions and money: Affluence as a missionary problem revisited, Orbis Books, Maryknoll, NY.

CBCA, Communauté Baptiste au Centre de l'Afrique, 2011a, Rapport du Président et Représentant Légal à la $33^{\circ}$ Assemblée Générale de la CBCA, Cession 2011, du 11 . 15 Septembre 2011.

CBCA, Department of Evangelism, Mission and Life of the Church of CBCA, 2011b, 'Effectifs des Pasteurs de la CBCA', unpublished document.

Center for Mission Mobilization, 2015, .XPLORE, CMM Press, Fayetteville.

Center for the Study of Global Christianity, 2015, 'Christianity in Africa by country', viewed 23 Nov. 2018, from https://www.gordonconwell.edu/ockenga/research/ .../ChristianityinAfricaFINAL.pdf

Communaute Baptiste au Centre de l'Afrique (CBCA), Departement des Jeunes et Enfants, 2013, 'Pour une jeunesse affermie et outillée', unpublished book.

Dayton, W.R. \& Siewert, R.A. (eds.), 1989, Mission handbook: USA/Canada protestant ministries overseas, Zondervan Publishing House, Grand Rapids, MI.

Eglise La Borne n.d., 'Le pasteur', viewed 04 November 2013, from http://www. laborne.cd/index.php/eglise/pasteur. accessed 04/11/2013

Gerhman, R. J., 2004, 'The Africa Inland Mission: Aspects of its history', Africa Journal of Evangelical Theology 23(2), 115-145.

Goheen, M.W., 2011, A light to the nations the missional church and the biblical story, Baker Academic, Grand Rapids, MI.

Groupes Bibliques Universitaires d'Afrique Francophone, 2013, viewed 04 November 2013, from http://gbuaf.org/gbuaf/web/fr/spip.php?article3

Hiltz, F., 2008, 'Go to the world! Go struggle, bless, and pray: Bishops, theological schools, and mission', Anglican Theological Review 90(2), 305-315, viewed 09
November 2012, from http://www.dacb.org/stories/kenya/hurlburt_charles. hovem.

Kighoma, E.K., 2012, 'Interview with the secretary of the Department of Mission and Life of the Church', 12 July, Goma.

Kohl, M.W., 2005, The church in the Philippines: A research project with special emphasis on theological education, OMF literature Inc., Mandaluyong City, Manila.

Maranz, D. E., 2001, African friends and money matters: Observation from Africa, SIL International and International Museum of Cultures, Dallas, TX.

Mutahinga, S.N. \& W'Isuka, P.K.M., et al. (eds.), 2006, Université libre des pays des grands lacs: Prospectus 2006-2007, Publications de I'ULPGL, Goma.

Mutahinga, S.N. \& Midiburo,N., 2011, Communauté Baptiste au Centre de l'Afrique: Compte rendu ya assemblee generale ya mara makumi tatu na tatu (33e AG) iliyofanyika pa Kikyo/Butembo tarehe, 11-15/09/2011. 
Pirouet, L., 1978, Black evangelists: The spread of Christianity in Uganda, Rex Collings, London.

Robert, D.L., 1994, 'Adoniram Judson Gordon 1836-1895', in G.H. Anderson, R.T Coote, N.A. Horner \& J.M. Philips (eds.), Mission legacies: Biographical studies of leaders of the modern missionary movement, Orbis Books, Maryknoll, NY.

Roberts, W.D. \& Siewert, J.A. (eds.), 1989, Mission handbook: USA/Canada Protestant Ministries Overseas, Zondervan Publishing House, Grand Rapids, MI.

Ryu, D.Y., 2001, 'Understanding early American missionaries in Korea (1884-1910) Capitalist middle-class values and the Weber thesis', Archives de sciences sociales des religions 46(113), 93-117, viewed 04 November 2013, from http://www.jstor org/stable/30116476.

Shelley, B. L., 1981, A history of conservative Baptists, Conservative Baptist Press, Wheaton, IL.

Scherer, J.A., [1999] 2005, 'Key issues to be considered in global mission today: Crucial questions about mission theology context, and expectations', in P.V. Martinson (ed.), Mission at the dawn of the $21^{\text {st }}$ century: A vision for the Church, Kirk House (ed.), Mission at the dawn of the
Publishers, Minneapolis, MN.

Stepp, P.L., 2005, Leadership succession in the world of the Pauline circle, Phoenix Press, Sheffield.
Steffem, T. \& Douglas, L.M., 2008, Encountering missionary life and work: Preparing for intercultural ministry, Baker Academic, Grand Rapids, Ml.

Stetzer, E., 2006, Planting missional churches: Planting a church that's biblically sound and reaching people in culture, B\&H Publishing Group, Nashville, TN.

Tuttle, R.G, 2006, The story of evangelism: A story of the witness to the gospel, Abingdon Press, Nashville, TN.

Unevangelized Africa Mission, 2013, Charles Hurlbert, viewed 13 November 2013, from www.californiacompanieslist.com/unevangelized-africa-mission-1qjmc/.

Wheeler 1989:1

Williams, J.F, 2012, 'The missionary message of the New Testament', in Barnett, M. \& Martin, R. (eds.), Discovering the mission of God: Best missional practices for the $21^{\text {st }}$ Century, IVP Academic, Downers Grove, IL.

W'Isuka, K.M, 2009, 'From maintenance Christianity to a holistic and comprehensive understanding of mission: A case study of churches in the North Kivu province of the Democratic Republic of the Congo', Master of Theology dissertation, Department of Missiology, University of South Africa.

Wright, C.J., 2006, The mission of God: Unlocking the Bible's grand narrative, IVP Academic, Downers Grove, IL. 